Article

\title{
The Combat against COVID-19 in Portugal: How State Measures and Data Availability Reinforce Some Organizational Values and Contribute to the Sustainability of the National Health System
}

\author{
Pedro Miguel Alves Ribeiro Correia * ${ }^{\mathbb{C}}$, Ireneu de Oliveira Mendes, \\ Sandra Patrícia Marques Pereira $₫$ and Inês Subtil 1 \\ Centre for Public Administration and Public Policies, School of Social and Political Sciences, \\ University of Lisbon, 1300 Lisbon, Portugal; imendes@iscsp.ulisboa.pt (I.d.O.M.); \\ spereira@iscsp.ulisboa.pt (S.P.M.P.); subtil.inesrh@gmail.com (I.S.) \\ * Correspondence: pcorreia@iscsp.ulisboa.pt
}

Received: 17 July 2020; Accepted: 10 September 2020; Published: 11 September 2020

check for updates

\begin{abstract}
Countries are facing a pandemic crisis in the context of a new disease from the coronavirus family, referred to as COVID-19. This article aims to present the main facts related to the fight against the pandemic from the perspective of the Portuguese governance, aiming to contribute to the knowledge of crisis management by political leaders as well as the performance of public entities. The present research was conducted through a quantitative approach, using data publicly provided by the Portuguese Directorate General of Health. An explanatory and descriptive study is presented about the current panorama, and yet to be shared good practices of crisis management and the relevance of organizational values in crisis management and crisis coordination are also discussed. Based on the lessons from Portugal, the authors suggest the relevance of organizational values and stakeholders' coordination as key factors in crisis situations, such as the current one.
\end{abstract}

Keywords: managing change; crisis management; strategic planning; coordination

\section{Introduction}

Nowadays, the world is facing a time of dramatic changes and demanding actions due to the biggest worldwide crisis of the 21st century. The results that monitor the situation and the developments are presented daily thanks to the countries' statistics. The new coronavirus disease, named COVID-19, caused by the SARS-CoV-2 virus, has led to the current pandemic scenario. The disease originated from Wuhan, Hubei, China, and has already 10,321,689 confirmed cases, 507,435 confirmed deaths, and the virus has already reached 216 countries [1].

The year 2020 began with this epidemic outbreak, which is now considered a global pandemic. The social, economic, and political impact is intense, and countries' governments react at different rates-with different measures and different impacts [2,3]. Therefore, questions about the before, during, and after the crisis start to arise.

This article aims to present the main facts related to the fight against the pandemic, from the perspective of Portuguese governance, since the pandemic beginning to the current phase-the mitigation phase-aiming to contribute to the knowledge of crisis management by political leaders, with the main focus on the public entities' performance. As this is a situation that brought together a large group of stakeholders, with different roles and targets, it is also important to talk about the organizational values associated with the public sector and other relevant ones [4-8]. 
To achieve this, the present article is structured as follows: first, a brief literature review on crisis management focused on the COVID-19 context is presented, followed by the methodological section. Afterwards, the results begin with an objective description in time and space related to the way in which governmental authorities' decisions were taken, focused on the legal steps and the Portuguese strategy. Then, a quantitative analysis is developed, aiming to respond to the established hypothesis "the mitigation measures developed and implemented by the Portuguese authorities have contributed unequivocally for the reduction of the Portuguese number of deaths". To enhance this paper, the importance of strategic planning and its coordination, from the central to the regional and the local level, will be briefly addressed since it contributes to the governmental agent's response to this demanding situation and helps in the decision-making process. Finally, the main conclusions will be highlighted, and a set of key factors will be approached by the authors, as well as recommendations for future crisis management research and development in the COVID-19 context.

\section{Crisis Management in the COVID-19 Context}

Public authorities may face crisis situations such as natural disasters, financial crisis [9], or terrorist attacks, epidemics, and failures in information and communication technologies [10]. Moreover, a crisis that affects one sector of society, ends up having strong impacts-more or less predictive-in other sectors. For instance, the economic and financial crisis of 2008 had an impact in some European justice systems [11-17]. However, the shape and dynamic of the crisis are constantly changing [18], and to appease it-quite often-depends on the different organizational values, in public organizations, and private organizations [4-8]. One of the biggest challenges of our current context has been the crisis management. Consequently, it is fundamental to elaborate national plans for crisis management and build robust structures for crisis management. According to the literature, COVID-19 disease is considered a biological disaster, with technological and social mitigating elements in its spread. Facing such a complex scenario must be a coordination between stakeholders, and the governance from each country must consider the cycle phases of the crisis management process in the most effective way [18].

The cycle of crisis management is commonly known as cycle PDCA: Plan, Do, Check and Act. Phase one deals with the crisis detection; phase two is the crisis itself; phase three is the expected adjustment of society, and it is fundamental to check what was carried out and what was effective in the crisis combat; lastly, phase four is the crisis evaluation and beginning to improve and recover from the crisis [19].

These phases are hard to separate individually since the governmental response depends on all mentioned phases. Probably, the most important one is preparation since it creates the roots for a quick and effective response. This can be given if the following conditions were present: trained human resources available, leaders with experience, proper communication, logistic and transport access, and action protocols for emergencies. Every type of crisis/disaster calls for different expertise ranges, but the initial action of the specific field is determinant. Since we are facing a biological crisis in the COVID-19 pandemic context, the primary action is from the Health field [18,19].

Alongside crisis management, it is crucial to refer to some management organizational elements that have an important role in the process of change management. Once we face a scenario of dramatic change with constraints and obstacles to overcome, some organizational elements facilitate and support the process, namely [20]:

- Knowledge transfer, which includes task specialization and interoperability. Task specialization supports organizations in embracing new skills and knowledge, helping as a consequence interoperability, by facilitating interchange of information and data.

- Knowledge conversation that includes identity and shared leadership. A person identity, or even an organization identity, affects management changes. People with different values, believes, and behaviors will affect differently the entire organization. Shared leadership-with different identities of people-is considered quite useful in change management situations since it allows 
different roles and responsibilities to rotate according to what is best for the situation, allowing the coordination and flexibility of the teams.

- Feedback to change which is the result of the whole management change process, and the consequence is the acceptance or resistance to changes.

Organizations must pay attention to these factors over implementing changes in their usual habits. This process is complex and uncertain, with different variables involved, and with different feedbacks [20]. In 2020, the Portuguese National Health Service celebrates 41 years of existence. Changes during all these years were embraced, and must be especially nowadays. The aim of the Portuguese National Health Service is to build a health policy to sustain universal and general scope, equal access, and the tendency to free assistance and services [21]. The Directorate-General of Health (DGS)-the responsible body for the regulation, guidance, health promotion activities, and disease prevention activities-follows the World Health Organization guidelines, and is also in close cooperation with civil protection entities and under governmental coordination. This public body assumes a determinant role in the follow up of the epidemiological situation by providing all the information related to the analyzed indicators used to monitor the process. In the epidemiological situation reports, indicators such as the following are approached: number of suspected cases, number of confirmed cases, number of nonconfirmed cases, number of cases in laboratory analysis, number of cases monitored by the health authorities, among others [22].

\section{Materials and Methods}

The present research was primarily conducted through a quantitative approach, with data publicly provided by the Directorate-General of Health of Portugal. The aim was to present an explanatory and descriptive study about the Portuguese current panorama and share good practices for crisis management, by answering the following hypothesis: "the mitigation measures developed and implemented by the Portuguese authorities have unequivocally contributed to the reduction of the number of deaths in Portugal".

Therefore, a set of important data from Portugal was collected, examined, and analyzed, namely the daily epidemiological situation reports from the Directorate-General of Health [22]. Portugal's current situation is due to the mitigation measures and to the organizational value of transparency in the government action. Therefore, based on the above-mentioned technical reports, an initial exponential projection modelled by the ordinary list squares method is presented, with the number of current deaths to transmit the importance of mitigation practices, in order to validate the hypothesis above. By using this quantitative method, it will be possible to address the influence (positive or negative) of mitigation measures. Therefore, this academic conventional method will present the scenario without the Portuguese mitigation actions, and the real scenario-with mitigation actions.

Besides the quantitative analysis, in order to reinforce this early academic research, a qualitative analysis is also presented to display the Portuguese panorama. A content analysis of the current Portuguese legal framework is presented and, based on the literature review, a descriptive analysis of the several Portuguese stakeholders was designed according to their response capacity versus their managing crisis impact.

\section{Results}

\subsection{The Combat against the Pandemic Crisis and the Portuguese Authorities' Response}

Based on the data from the Portuguese epidemiological reports, Figure 1 presents the Portuguese available information from a transversal point of view, by providing data since the beginning of the pandemic (3 March 2020) regarding suspected cases, confirmed cases, number of cases in laboratory analysis, and number of cases monitored by health authorities. The crisis evolution is quite visible in Figure 1-showing the stability of confirmed cases without any standout peak to highlight. The crisis evolution came with a set of restrictive measures. These measures were aligned with the pandemic 
crisis development phases/levels, namely, the contention phase/level and the mitigation phase/level, and a more demanding stage-a synonym of crisis; both levels are framed in the response phase (Table 1). At the time this paper was written, the country was in the mitigation phase (3.2-community transmission). Portugal had adopted the following long-term strategy: in phase one, regarding preparation and contention, the management must be concentrated and reinforced to assure a careful follow-up in the governmental response, and also to guarantee adequate and efficient resource management. In phase two, the extended contention is crucial for the expansion of diagnosis and treatments. In the mitigation and recovery phase, all health services must have the capacity to deal with a slight to moderate COVID-19 case, since the severe cases must be managed in a clinical environment. As the operation of several systems, functions, and infrastructures that support life, as we know it is severely threatened, and the causes and impacts remain unpredictable, we might speak of a cross-border crisis [23].

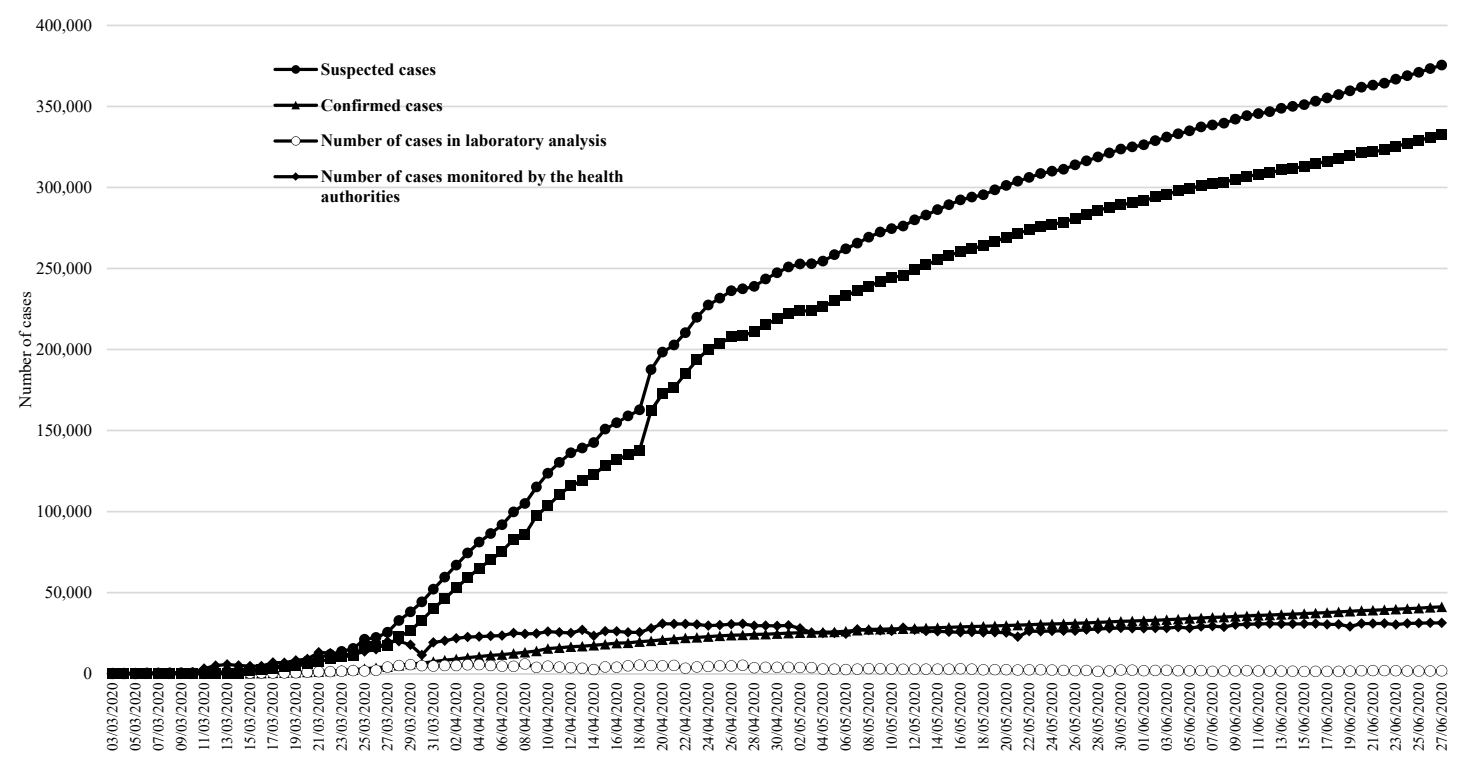

Figure 1. Evolution on the number of suspected cases, number of confirmed cases, number of nonconfirmed cases, number of cases in laboratory analysis, and number of cases monitored by the health authorities. Source: own elaboration, based on epidemiological situation reports from DGS [22].

Table 1. Warning levels and the Portuguese response to COVID-19 crisis.

\begin{tabular}{|c|c|c|}
\hline Phase & Designation & Definition \\
\hline Preparation & - & There is no epidemic outside Portugal. \\
\hline \multirow{6}{*}{ Response } & \multirow{2}{*}{$\begin{array}{l}\text { Level } 1 \\
\text { Contention }\end{array}$} & $\begin{array}{l}\text { 1.1-Identified an epicentre outside Portugal, with } \\
\text { international transmission. }\end{array}$ \\
\hline & & 1.2-Imported cases in Europe. \\
\hline & \multirow{2}{*}{$\begin{array}{l}\text { Level } 2 \\
\text { Extended Contention }\end{array}$} & 2.1-Secondary chains of transmission in Europe. \\
\hline & & 2.2-Imported cases in Portugal without secondary chains. \\
\hline & \multirow{2}{*}{$\begin{array}{l}\text { Level } 3 \\
\text { Mitigation }\end{array}$} & 3.1-Local transmission in closed environment. \\
\hline & & 3.2-Community transmission. \\
\hline Recovery & - & Disease activity starts to decrease in Portugal, and in the world. \\
\hline
\end{tabular}

Taking into account the evolution of the Portuguese situation, although it is not yet possible to calculate their effects on society at a certain and reliable level, it is possible to state that the measures were 
adopted in a top-down viewpoint-since they were enacted by the Government with the collaboration of the President of the Republic and the Portuguese Parliament. Although Portugal faces a positive collaboration between the different crisis management stakeholders, there are situations that concern the population. These situations derive from the pandemic impact, which has distinctive implications in the national territory (Table 2).

Table 2. Cases distribution and number of deaths by territory on 28/06/2020.

\begin{tabular}{ccc}
\hline Territory & $\begin{array}{c}\text { Number of Confirmed } \\
\text { Cases }\end{array}$ & Deaths \\
\hline North & 17,445 & 816 \\
Centre & 4080 & 248 \\
Alentejo & 18,361 & 463 \\
Algarve & 467 & 4 \\
Autonomous Region of Azores & 595 & 15 \\
Autonomous Region of Madeira & 149 & 15 \\
\hline
\end{tabular}

Source: own elaboration based on [22].

Aiming to minimize the pandemic evolution impact in the national territory, it was declared a State of Emergency, through the Decree of the President of the Portuguese Republic n. ${ }^{\circ} 14-\mathrm{A} / 2020$, of 18 March [25]. This exceptional situation required extraordinary restrictive measures on constitutional rights and liberties. In Table 3 the set of measures implemented by the Portuguese authorities is presented.

The north of the country was one of the most affected zones. It is believed it had to do with the initial outbreak in Portugal that had the greatest expression in this region, since the majority of national footwear companies are in the north, and several companies' bodies were recently in footwear fairs in countries, such as China and Italy-where the combat against the virus had already begun in December and February, respectively. However, since the State of Emergency ended, the Metropolitan Area of Lisbon started to increase its number of confirmed cases-the most affected zones are in the suburbs and not in the city center [22].

The government highlighted that the implemented restrictions were extremely necessary and aligned with the effort to contain the pandemic crisis evolution. Therefore, a set of measures were undertaken, aiming to confine citizens to their houses, trying to minimize circulation, as well as the spread of the virus. Portugal has been fighting to reverse the case increase by the adoption of these isolation measures and by embracing several protective sanitary policies [26].

Table 4 presents a comparative perspective on the international response capacity, in relation to decision-making. It can be concluded, after analyzing Table 4, that the Portuguese Government presented a firm and quick response to COVID-19. Portugal suspended events, closed schools and nonessential stores, nonessential travel was forbidden, borders were closed, and nonessential production stopped before the third death was registered from coronavirus in Portugal. This scenario shows a positive response capacity from the Portuguese governance, and a preventive posture that can prove to be quite decisive in the long-term effects in the country regarding social and economic changes.

\subsection{The Mitigation Evolution in Portugal}

The hypothesis in this study is "the mitigation measures developed and implemented by the Portuguese authorities have unequivocally contributed to the reduction of the number of deaths in Portugal". To test the aforesaid hypothesis, an initial exponential projection modelled by the ordinary list squares method was carried out with data collected from the daily epidemiological situation reports from the Directorate-General of Health [22]. 
Table 3. State of Emergency measures in Portugal.

\begin{tabular}{l}
\hline 1-Mandatory confinement at home or at health facilities. \\
\hline 2-Healthcare fences established. \\
\hline 3-Temporary ban on movements and unjustified stays at public roads. \\
\hline 4-Services requirement and movables and healthcare facilities use. Commercial, industrial, enterprises establishments (and other productive units) use. \\
\hline 5-Enterprises/establishment/production resources opening, operation, and functioning imposition. \\
\hline 6-Enterprises/establishment/production resources closure or limitations. \\
\hline 7-Imposition to public or private employees to work, or, if needed, to perform their function in a different location, in different entities, and in different labour conditions and schedules of the corresponded \\
employment bond. \\
\hline 8-The suspension of the right to strike. \\
\hline 9-Border controls. \\
\hline 10-Reunions and manifestations limitation or prohibition—of which the involved number may boost the coronavirus transmission. \\
\hline 11-Limitation or prohibition of religious celebrations or other cult events. \\
\hline 12-Prohibition to resist the public authorities' orders.
\end{tabular}

Source: own elaboration based on [25].

Table 4. Number of days between the third death caused by coronavirus and the measures implemented by European countries.

\begin{tabular}{|c|c|c|c|c|c|c|c|}
\hline European Countries & Suspended Events & Schools Closure & $\begin{array}{c}\text { Non-Essential Stores } \\
\text { Closures }\end{array}$ & $\begin{array}{c}\text { Non-Essential Travels } \\
\text { Forbidden }\end{array}$ & Borders Closure & $\begin{array}{c}\text { Non-Essential } \\
\text { Production Stopped }\end{array}$ & Third Death Confirmed \\
\hline Italy & 9 days & 9 days & 14 days & 14 days & - & 30 days & $25 / 02 / 2020$ \\
\hline France & $0 *$ & 13 days & 11 days & 14 days & - & - & $03 / 03 / 2020$ \\
\hline Spain & 4 days & 9 days & 9 days & 10 days & 10 days & 23 days & $06 / 03 / 2020$ \\
\hline United Kingdom & 8 days & 14 days & 12 days & 15 days & - & - & 09/03/2020 \\
\hline Belgian & 2 days & 3 days & 5 days & 5 days & 8 days & - & $12 / 03 / 2020$ \\
\hline Germany & 8 days & 3 days & - & 9 days & 4 days & - & $12 / 03 / 2020$ \\
\hline Greece & $0^{*}$ & $0^{*}$ & 1 day & 8 days & $0^{*}$ & - & $15 / 03 / 2020$ \\
\hline Poland & 0 * & 1 day & $0 *$ & 10 days & 0 * & - & $15 / 03 / 2020$ \\
\hline Sweden & 0 * & - & - & - & - & - & $16 / 03 / 2020$ \\
\hline Austria & 0 * & 0 * & 0 * & 0 * & - & - & $17 / 03 / 2020$ \\
\hline Portugal & 0 * & 0 * & 0 * & 0 * & 0 * & - & $20 / 03 / 2020$ \\
\hline Hungary & $0^{*}$ & 0 * & 0 * & 7 days & 0 * & - & $21 / 03 / 2020$ \\
\hline Check Republic & $0^{*}$ & 0 * & 0 * & $0^{*}$ & 0 * & - & $25 / 03 / 2020$ \\
\hline
\end{tabular}

${ }^{*}$ Zero days means that the measure was implemented before the third death registered from coronavirus. Source: own elaboration based on [27]. 
In crisis management, good mitigation practices in the fight against the pandemic might lead to a scenario such as the one presented in Figure 2. Portugal, by adopting mitigation behaviors, was able to contradict the initial exponential projection of deaths, regarding the first day's fatalities. Without mitigation, projection based on the first two days of deaths in Portugal presented almost 4000 deaths after 15 days. However, with the mitigation measures implemented in the European country, after 96 days, there were less than 1600 deaths than was expected without mitigation.

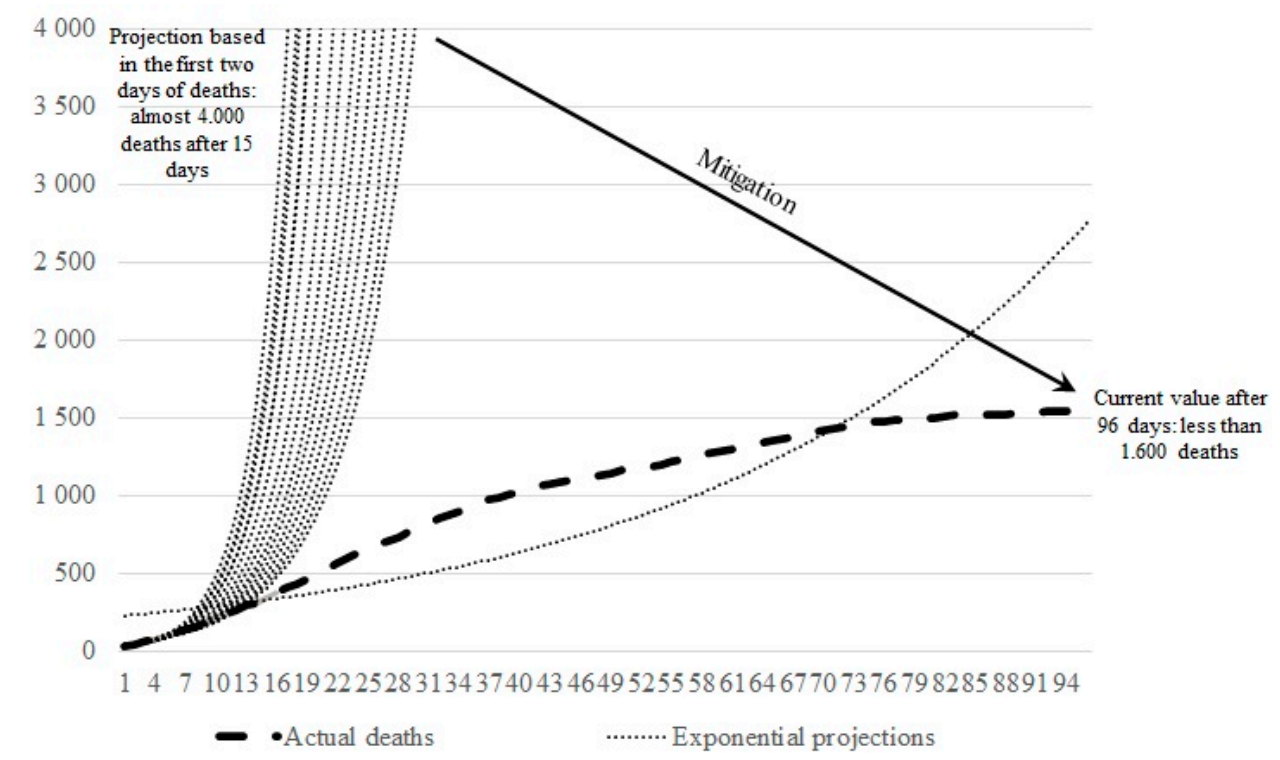

Figure 2. Projected deaths according to the mitigation evolution (in days). Source: own elaboration, based on [22].

Therefore, the stated hypothesis is confirmed and validated: the mitigation measures developed and implemented by the Portuguese authorities have unequivocally contributed to the reduction in the number of deaths in Portugal.

\subsection{The Importance of Governmental Collaboration and Coordination in the Combat against the Crisis}

In crisis managing, coordination is not an obvious characteristic [23]. Entities' responses are not always based on planning - when there is planning; instead, the response is reactive to the events; therefore, the results are never more effective. Besides that, a crisis does not banish the already existing conflicts between authorities and other public players in the daily connections before a crisis. An effective response to a crisis, for the most part, results from a planning process, regularly reviewed in a continuous improvement perspective [28,29].

This effective response quite often depends on different organizational values, in public and private organizations [4-8]. First, it is important to define the term values: "values are criteria, beliefs or basic assumptions that can be placed in an order and that go beyond specific situations, guiding the specific actions of individuals, groups, organizations, institutions and companies, contributing to their respective identity" [5] (p.989).

There are a series of values traditionally linked to public administration, which transpose the social responsibility and the principles associated with citizenship, sustainability, accountability, and integrity. Therefore, the traditional values are legality, incorruptibility, and impartiality [4-8]. However, there are currently a set of values shared between public and private organizations, namely, accountability, expertise, reliability, effectiveness, and efficiency, as well as other organizational values recognized in the scientific academy: collegiality, obedience, transparency, dedication, self-fulfillment, appreciation of citizenship, usability, social justice, and sustainability [4-8]. These organization values may enter into conflict, depending on the situation that is faced. For example, the value sustainability may 
conflict with the value of effectiveness or efficiency. In this specific case, an effective response requires interinstitutional and intergovernmental coordination [28,29]—all stakeholders with different aims, political positions, and, especially, those with different but linked organizational values. We face a demanding coordination, which requires accuracy and willingness from all parts, in order to succeed and restore the old normal.

To achieve this, a set of institutional and context analysis must be considered to assess the areas which requires more strategic alignment-aiming to increase it and contribute to gaining a competitive advantage from institutions. In the public sector, this might be considered a synonym for a more efficient and high-quality service [30]. The Portuguese outlook was used to select several entities that contribute, directly or indirectly, to combatting the current crisis (Figure 3).

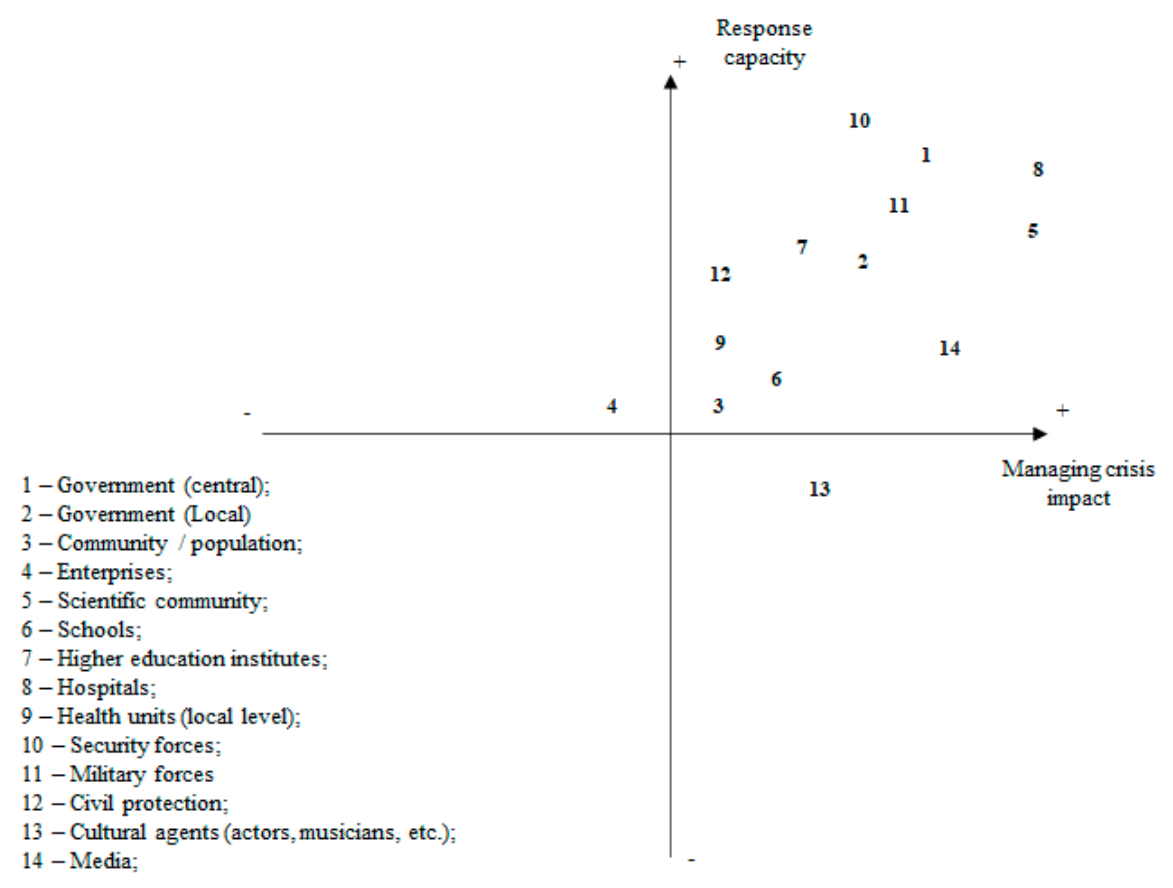

Figure 3. Response capacity versus managing crisis impact. Source: own elaboration.

\section{Discussion}

Figure 3 allows the understanding of the positive and negative actions from a set of entities/ organizations in managing the crisis. For this analysis, two criteria were considered: the response capacity offered and the impact on crisis management. Stakeholders are also important in the crisis combat, although with different strengths and expressions. Brief details of the organization's actions of Figure 3 are set out below.

Central government action proved to be positive, from a national and international perspectiveseveral European countries were facing the combat against the virus before Portugal. It is believed that this positive action is based on the importance given to planning, probably due to the tragic death of 64 Portuguese citizens in 2017, who are still remembered today.

Local governments have also performed an important role, although with different expressions and intensities. On one hand, some municipalities, based on their size and management response, can develop a set of actions, whose impact is visible even in the international scenario. For instance, Lisbon and Porto managed —autonomously — to launch a set of efforts to acquire medical equipment, namely protection material to health agents, through the solicitation for personal protection equipment, or the ventilation acquisition process (fundamental for situations in which the infected are more fragile or the disease is advanced). On the other hand, there are municipalities with a more contained action, when the human, financial, and organizational resources are not sufficient to allow those municipalities to provide a full and adequate response-in the cases where there are already a significant number 
of infected people- or a response that allows the local governments to be prepared and anticipate the future scenario. In this framework, the strategic alignment between the Central Administration (Government) and the Autonomy Administration (autarchies) is decisive. In this regard, the prime minister appointed five secretaries of state as regional authorities to coordinate the execution of the state of emergency declaration. The focus will be in the health services coordination, Social Security coordination, and businesses support.

The community has a decisive role, and if the government guidelines are respected and complied, the community may leave the current confinement sooner. Therefore, noncompliance situations must not happen.

Enterprises were possibly the organizations where the impact was felt to a greater extent. This caused a higher number of petitions to adopt the labor regime named layoff. Otherwise, several enterprises would have to close their doors, since they stopped being able to invoice or even operate normally, because they were not covered by the labor activities defined by the government with permission to keep working-for example, those using the teleworking option. For that matter, the Portuguese government established a series of measures aiming to maintain jobs, securing a support in terms of liquidity.

The scientific community has a core role. It is called to intervene at an early stage, first with the objective of investigating the coronavirus genetic code and then, to move forward on the question of creating a vaccine-which in the best scenario, will take about a year.

Another set of organizations was faced with a hard scenario to manage-we are now speaking about schools and all higher education institutions. On one hand, schools were closed, and the guided study was dynamized with exercises shared by teachers, which should be carried out at home. For instance, the so-called "Telescola"—educational television—started on 20 April 2020 for the basic education of students. On the other hand, the higher education institutions acted in different ways and different rhythms. Some higher education institutions managed to adopt distance learning, relying on the potential of online platforms; however, others are not in this evolutionary state.

Hospitals are on the front line of combat against the pandemic outbreak, and their action is always limited regarding the current scenario. While the call for medical equipment that aims to give response to several solicitations restricts their action, sometimes the lack of human resources in intensive care medicine is also a regularly highlighted factor by hospital boards, as potentially damaging to a favorable response, since the hardest situations are the ones in intensive care and when a technical body is not accessible to give a fast response to the demand, which is significant. Still in the heath field, local health units have performed a less expressive role, being ready to support whatever is needed, considering their reduced capacity to respond to the current situation.

In regard to the security forces, they have performed an important role in relation to rule compliance-mandatory retreat by the community.

The military forces have also a relevant role in the combat against the outbreak-through the establishment of field hospitals, where several tests are made, or through the decontamination procedure in the households where users were infected, by using their own nuclear, biological, chemical, and radiological defense units. Additionally, in this regard, the military laboratory managed to carry out tests and produce disinfectant gel.

Lastly, the media, with an important role, performed the guided and technical information diffusion and sharing to the community. Several campaigns of awareness and prevention are carried out by the four Portuguese open signal channels (RTP1, RTP2, SIC, TVI e RTP3), through awareness actions and clarification action based on technical and scientific grounds.

These multiple stakeholders involved in the combat against COVID-19 also have an impact at the international level. Multiple stakeholders, with different organizational values, added complexity; therefore, without proper coordination and the implementation of good governance systems, problems regarding lack of discoordination, conflicting, counterproductive, and even dangerous measures may appear. Above all, a domestic scenario is presented, although at a superior level, the same happens with 
countries and supranational entities. An example of the importance of these stakeholders' coordination is when China banned domestic flights, but international ones were still permitted. This lack of coordination between stakeholders led to the virus spread.

\section{Conclusions}

In a crisis such as the current one, the community expects leaders to reduce uncertainty and provide an authoritative image as an important synonym for governmental response capacity. This research presents a good example on how mitigation actions can positively influence the spread of the virus in countries, validating the hypothesis "the mitigation measures developed and implemented by the Portuguese authorities have unequivocally contributed to the reduction of the number of deaths in Portugal".

Although we are in full management of the crisis, we can anticipate that it will result in a reservoir of possible lessons for planning and managing crisis situations. Thus, it is important that, after the current pandemic is over, all institutions can learn their lessons so that, consequently, good practices can be designed and the necessary policies formulated. In addition to cognitive and institutional barriers to learning, the design of the lessons is limited by the role of these lessons in determining the impact that crises have on society [31]. At a time when we are beginning to discuss the possibility that after the outbreak is overcome, the outbreak will return after the summer, it is urgent that all the actors are trained on what they will have to do to prepare for situations like the current one, and are able to anticipate the effects of a future replica, taking into account the current social earthquake.

Managing a crisis implies an articulation of organizational values, which might be considered as key factors to implement strategies and fulfill the main mission-recovery from the crisis we are living through. In the Portuguese case, it is important to highlight the legality value, in regard to the Portuguese regulation implemented [25]; the accountability value towards the citizen by all the technical and medical information that was diffuses; and, moreover, the reliability value of the citizens in the government actions and decisions [32]. Another crucial value is government transparency, highly linked to the accountability, and yet the appreciation of citizenship [28,29]. It is also important to mention the values related to the efficiency and effectiveness of the measures applied in the community-fundamental to the mitigation process.

Finally, the value of sustainability, in relation to the National Health System, which is in fact the main aim of the mitigation measures applied is considered. Sustainability is a key value in the panorama the world is living in. It is fundamental to maintain the National Health Systems in a stable condition in order to answer the needs of civil society, without compromising the long-term sustainability for next generations. Mitigation measures must hold this key value in their action center, continuing to develop efforts to contain the pandemic crisis evolution. When undertaking this, actions go side-by-side with National Health System future subsistence, and therefore, the civil society needs will be rightfully approached and answered. In this specific case, Portugal has adopted several mitigation measures clearly linked to the conditions mentioned above (Table 3 ). These actions aimed to protect the citizens by trying to minimize circulation with isolation measures and by embracing several protective sanitary policies. In this way, by embracing social isolation and all protective measures, the virus can be monitored effectively by the Portuguese National Health System, and consequently, it can provide the citizens with COVID-19 demands, and satisfy the medical needs of Portuguese society today and in the near future.

The National Health System alongside the mitigation practices are fighting against the virus spread. Although, reflecting in long-term, we can also conclude that our current situation is a call for the governance to redesign the worldwide health systems and the way healthcare management is developed and implemented. New healthcare business models should be studied, aiming to certify the world economy, sustainability, and the quality life for the patients [33].

In this specific case, we are already using coproduction practices and telemedicine-innovative technologies are used, guaranteeing the distance between patients and professionals, through online 
medical appointments, reducing the possibilities of infection. This experience should be seen as a lesson, or even a case study to examine carefully. The majority of patients are already in their houses, which plays a pro-active part in its own treatment, showing that coproduction in the health field is possible and already used with other illnesses such as heart failure [33]. Practices of coproduction suggest a safer connection these days, and it is also economic for the health systems by improving the organization management and facilitating the workflow. However, change takes time, and this specific change is even harder since we are facing a technical—with the need of technological support-and cultural change. However, important steps towards E-Health and coproduction were given in this pandemic scenario looking forward to the sustainability of the health systems and helping the mitigation of the virus [33].

The share of good mitigation practices in the combat against the pandemic might lead to a scenario such as the one presented in Figure 2. Portugal, by adopting the mitigation behaviors, was able to contradict the initial exponential projection of deaths, regarding the first day's fatalities. The good practices shared in this paper may be an important aid to other countries' public administrations, in their effort to combat and mitigate this global pandemic, which is between domestic experiences and concerted global policies. Portugal might be seen as an example of good practices in pandemic crisis management, since with the early response to the virus appearance, rooted in the valuable stakeholders' coordination, it was possible to control the spread of the virus, and the implementation of several mitigation measures presented favorable results and positive answers from the Portuguese citizens. Future studies should approach the long-term effects of the mitigation measures implemented in Portugal, particularly concerning the positive stakeholders' coordination as a strong element to be considered in future crisis management. Additionally, future investigations may analyze and compare different actions from different countries in order to understand how countries faced the possibility to embrace E-Health and coproduction in the pandemic outbreak. This is a window of opportunity to study different healthcare models.

Author Contributions: Conceptualization, P.M.A.R.C. and I.d.O.M.; methodology, P.M.A.R.C.; software, P.M.A.R.C., I.d.O.M., S.P.M.P. and I.S.; validation, P.M.A.R.C., I.d.O.M., S.P.M.P. and I.S.; formal analysis, P.M.A.R.C. and S.P.M.P.; investigation, P.M.A.R.C. and I.d.O.M.; resources, P.M.A.R.C., I.d.O.M., S.P.M.P. and I.S.; data curation, P.M.A.R.C., I.d.O.M., S.P.M.P. and I.S.; writing-original draft preparation, P.M.A.R.C., I.d.O.M. and S.P.M.P.; writing-review and editing, P.M.A.R.C. and S.P.M.P.; visualization, P.M.A.R.C.; supervision, P.M.A.R.C.; project administration, P.M.A.R.C.; funding acquisition, P.M.A.R.C. All authors have read and agreed to the published version of the manuscript.

Funding: This research was funded by the Research Unit funded by Portuguese National Funds through FCT-Fundação para a Ciência e Tecnologia under project UID/CPO/00713/2020.

Conflicts of Interest: The authors declare no conflict of interest.

\section{References}

1. World Health Organization. Available online: https://www.who.int/emergencies/diseases/novel-coronavirus2019 (accessed on 1 July 2020).

2. Tashiro, A.; Shaw, R. COVID-19 Pandemic Response in Japan: What Is behind the Initial Flattening of the Curve? Sustainability 2020, 12, 5250. [CrossRef]

3. Marco-Franco, J.E.; Guadalajara-Olmeda, N.; González-de Julián, S.; Vivas-Consuelo, D. COVID-19 Healthcare Planning: Predicting Mortality and the Role of the Herd Immunity Barrier in the General Population. Sustainability 2020, 12, 5228. [CrossRef]

4. Bilhim, J.F.A.; Correia, P.M.A.R. Differences in perceptions of organizational values of candidates for top management positions in the State's Central Administration. Sociologia 2016, 31, 81-105. [CrossRef]

5. Correia, P.M.A.R.; Bilhim, J.F.A. Differences in perceptions of organizational values of public managers in Portugal. Braz. J. Public Adm. 2017, 51, 987-1004. [CrossRef]

6. Correia, P.; Mendes, I.; Freire, A. The Importance of Organizational Values in Public Administration: A Case Study Based on the Workers' of a Higher Education Institution Perception. Rev. CLAD Reforma y Democr. 2019, 73, 227-258. 
7. Correia, P.M.A.R.; Pereira, J.N. Perceptions of organizational values in the Portuguese Armed Forces: Proposal for a theoretical-methodological model. Public Sci. Policies 2018, 4, 117-133. [CrossRef]

8. Correia, P.; Pereira, J. The recent history of research on public values as told by google scholar: Publications in portuguese and spanish in the 20th and 21st centuries. Rev. Simbiótica 2017, 4, 36-51.

9. Cretu, A.Ş.; Stanef, R.M. Effects of global financial crisis. Metal. Int. 2010, 15, 165-168.

10. Tierney, K. The Social Roots of Risk: Producing Disasters, Promoting Resilience; Stanford University Press: Standford, CA, USA, 2014.

11. Correia, P.; Videira, S. Troika's Portuguese Ministry of Justice Experiment: An Empirical Study on the Success Story of the Civil Enforcement Actions. Int. J. Court Adm. 2015, 7, 37-49. [CrossRef]

12. Correia, P.; Videira, S. Troika's Portuguese Ministry of Justice Experiment, Part II: Continued positive results for civil enforcement actions in Troika's aftermath. Int. J. Court Adm. 2015, 8, 20-31. [CrossRef]

13. Guimarães, T.; Gomes, A.; Correia, P.; Jesus, I.; Piazentin, T. Role conflict and role ambiguity in the work of judges: The perceptions of Portuguese judges. Braz. J. Public Adm. 2017, 51, 927-946.

14. Correia, P.; Dias, M.; Gonçalves, D.; Novais, Z.; Pereira, S. Troika's Portugueses Ministry of Justice Experiment, Part III: MoU Results Based on an Empirical Study of Special Revitalization Procedure Performance. In Proceedings of the Administration of Justice Meeting-EnAJUS, Brasília, Brazil, 2019.

15. Correia, P.M.A.R.; Dias, M.T.V.C.; Novais, Z.D.J.; Gonçalves, D.L. Troika's Portuguese Ministry of Justice Experiment: MoU Results based on an Empirical Study of the Bankruptcy, Insolvency and Corporate Recovery Actions Performance. In Proceedings of the Administration of Justice Meeting-EnAJUS, Brasília, Brazil, 2019.

16. Correia, P.; Dias, M.; Gonçalves, D.; Novais, Z.; Pereira, S. Special Revitalization Procedures: Additional Empirical Contribution on the Results of TROIKA'S Experiment in the Portuguese Ministry of Justice. Lex Hum. 2018, 10, 123-146.

17. Correia, P.M.A.R.; Videira, S.A.; Mendes, I.O. Troika's Portuguese Ministry of Justice Experiment: Dissipation of Doubts about Success, Continuation and Confirmation of Positive Results. Pensam. Am. 2019, 12, 40-53.

18. Rodrigues, K.F.; Carpes, M.M.; Raffagnato, C.G. Disaster preparedness and response in Brazil in the face of the COVID-19 pandemic. Braz. J. Public Adm. 2020, 54, 614-634. [CrossRef]

19. Mitroff, I.I.; Shrivastava, P.; Udwadia, F.E. Effective crisis management. Acad. Manag. Exec. 1987, 1, $283-292$. [CrossRef]

20. Binci, D.; Belisari, S.; Appolloni, N. BPM and change management: An ambidextrous perspective. Bus. Process Manag. J. 2020, 26, 1-23. [CrossRef]

21. Felix, J.; Ferreira, D.; Afonso-Silva, M.; Gomes, M.V.; Ferreira, C.; Vandewalle, B.; Marques, S.; Mota, M.; Costa, S.; Cary, M.; et al. Social and economic value of Portuguese community pharmacies in health care. BMC Health Serv. Res. 2017, 17, 606. [CrossRef]

22. Direção-Geral da Saúde. Available online: https://covid19.min-saude.pt/relatorio-de-situacao/ (accessed on 28 June 2020).

23. Boin, A. The new world of crises and crisis management: Implications for policymaking and research. Rev. Policy Res. 2009, 26, 367-377. [CrossRef]

24. Direção-Geral da Saúde-DGS. Available online: https://www.dgs.pt/documentos-e-publicacoes/planonacional-de-preparacao-e-resposta-para-a-doenca-por-novo-coronavirus-covid-19-pdf.aspx (accessed on 28 June 2020).

25. Decree of the President of the Portuguese Republic n. ${ }^{\circ}$ 14-A/2020. 18 March 2020. Available online: https: //dre.pt/web/guest/home/-/dre/130399862/details/maximized (accessed on 28 June 2020).

26. Pais, R.J.; Taveira, N. Predicting the evolution and control of the COVID-19 pandemic in Portugal. F1000Research 2020, 9, 283. [CrossRef]

27. Politico. Available online: https://www.politico.eu/article/europes-coronavirus-lockdown-measures-compared/ (accessed on 28 June 2020).

28. Correia, P.M.A.R.; Mendes, I.O.; Bilhim, J.A.F. Collaboration Networks as a Factor of Innovation in the Implementation of Public Policies. A Theoretical Framework Based on the New Public Governance. Lex Hum. 2019, 11, 143-162.

29. Correia, P.M.A.R.; Mendes, I.O.; Bilhim, J.A.F. The Importance of Collaboration and Cooperation as an Enabler of New Governance at the Local Level: A Comparative Analysis. Lex Hum. 2019, 11, 110-128.

30. Santos, A.J.R. Gestão Estratégica. Conceitos, Modelos e Instrumentos; Escolar Editora: Lisbon, Portugal, 2008. 
31. Boin, A.; Lodge, M. Designing Resilient Institutions for Transboundary Crisis Management: A Time for Public Administration. Public Adm. 2016, 94, 289-298. [CrossRef]

32. Correia, P.; Jesus, I.; Mendes, I. The privatization of the public sector: The importance of the expression "public interest" in modern public administration. Pensam. Am. 2017, 10, 80-94.

33. Palozzi, G.; Binci, D.; Appolloni, A. E-Health \& co-production: Critical drivers for Chronic Diseases Management. In Service Business Model Innovation in the Healthcare and Hospital Management Models, Strategies, Tools; Mario, A., Pfannstiel, C.R., Eds.; Springer: Vienna, Austria, 2017.

(C) 2020 by the authors. Licensee MDPI, Basel, Switzerland. This article is an open access article distributed under the terms and conditions of the Creative Commons Attribution (CC BY) license (http://creativecommons.org/licenses/by/4.0/). 